\title{
Optimization of Experimental Biomethanation Applied to Poultry Droppings for Better Energy Valorization
}

\author{
Ghariani. I, Najar. T
}

\begin{abstract}
National Agronomic Institute in Tunis, Animal Production Department University of Carthage, Tunis, Tunisia
\end{abstract}
\begin{abstract}
The fight against climate change is first and foremost passed by the reduction of greenhouse gases (GHG). Mainly in the form of methane $\mathrm{CH}_{4}$, the GHGs emitted by the waste originate from the decomposition of organic matter which is more commonly known as Anaerobic Digestion (AD) or Biomethanation. Livestock manure is one of the major hazards to the environment and human health due to the nuisances and pollution generated. The present study consists of optimizing the methane fermentation applied to poultry droppings. This optimization focuses on the daily monitoring of experimental digesters, on the physico-chemical characterization of the inputs used and on the study of the effect of temperature and inoculum changes on the daily production of biogas and its composition $\left(\mathrm{CH}_{4}, \mathrm{CO}_{2}\right.$ and $\mathrm{H}_{2} \mathrm{~S}$ ). The main results show, on the one hand, that the stability of the DA process after initial filling depends on experimental conditions, the general characteristics of the anaerobic digester, the initial biomass activity and the nature of the introduced inoculum. On the other hand, the production of biogas is better at a temperature of $35^{\circ} \mathrm{C}$ than at a temperature of $55^{\circ} \mathrm{C}$ and the addition of the inoculum has improved the production of biogas and the $\mathrm{CH}_{4}$ content, especially the use Of liquid poultry digestate.
\end{abstract}

Keywords- Anaerobic digestion, poultry droppings, energy characterization, quantitative and qualitative monitoring, Biogas.

\section{INTRODUCTION}

Nowadays, the problems of pollution; rising oil prices and the scarcity of fossil fuels, climate change and greenhouse gas emissions, biodiversity conservation and the conservation of natural environments are of increasing concern. Indeed, man has become aware of the reality of the situation and is becoming more and more vigilant towards the environment that surrounds it. The intensification of agricultural and agri-food production in order to satisfy the growing demand for human and animal food through the application of intensive livestock farming methods contributes to environmental damage, mainly through the rejection of livestock and untreated or poorly managed industrial effluents. As livestock manure is part of agricultural bio-waste, it can be used as a renewable energy source.

The poultry sector occupies a major place in the Tunisian diet with a consumption of $15.1 \mathrm{~kg} /$ inhabitant in 2010 according to [1]. This development can highlight this sector and can further increase the livestock societies and subsequently the quantities of poultry manure produced. Wastes generated during poultry farming are basically of three types: solid, pasty and liquid. Solid wastes or manure are all poultry manure mixed with a straw or wood chip carrier [2]. They have been traditionally used as an organic fertilizer by direct spreading on the ground. Pasty waste, called droppings from laying hens, and liquid manure called slurry.

The harmful discharges generated by poultry manures are due to the decomposition of organic matter which is known as methane fermentation or Anaerobic Digestion (AD). AD is a process both old and new. It is a biological process that takes place in the absence of oxygen and during which the organic matter is converted into biogas (mainly composed of methane and carbon dioxide). These are mainly bacteria and archae (microorganisms close to bacteria) who realize these conversions. This transformation is complex, as it is a case of waste from a solid form to a soluble form that can be used by bacteria [3]. $\mathrm{AD}$ is therefore a natural process taking place in marshes, sediments, but also in the digestive system (rumen) of animals such as mammals and certain insects (termites).

This work aims at studying methane fermentation, applied to Poultry Droppings (PD), established at the level of experimental digesters by developing quantitative and qualitative monitoring. Secondly, the possibility of optimizing the experimental biomethanisation of PD is studied: Effect of change of recovery medium of the droppings to be tested and the effect of change of temperature (mesophile and thermophilic) and of Inoculum. 


\section{MATERIALS AND METHODS}

2.1. Sampling and physico-chemical characterization of PD

This characterization aims to evaluate the by-products resulting from the breeding of laying hens on the qualitative level

\subsubsection{Sampling}

For the physicochemical characterization several average samples of PD were taken from laying hens in several regions in Tunisia. The sampling was carried out as follows: The constitution of a small representative sample is tricky, since most often it is heterogeneous products and the number of samples may vary according to the circumstances.

Chicken droppings are very often recovered on carpets placed under the rearing cages. In this case, it is sufficient to make several samplings at several points distributed along the length and level of each battery stage. In the case where the droppings are stored in pits, the height of the droppings may be large. Fork or shovel sampling is not easy. It may be preferable to use a corer for pasty products [4]. In our study, the tested droppings are recovered from two recovery sites (Pit and mat).

\subsubsection{Physico-chemical characterization of PD}

The physicochemical parameters estimated during this work are: $\mathrm{pH}$, Dry Matter (DM), Mineral Matter (MM) and Organic Matter (OM), Total Organic Carbon (TOC), $\mathrm{C} / \mathrm{N}$ ratio and Volatile Fatty Acids (VFA).

\subsubsection{1. pH}

$\mathrm{pH}$ is an indicater of the acidity or alkalinity of the sample. It is measured after dissolving $10 \mathrm{~g}$ of the sample in $50 \mathrm{ml}$ of distilled water. The method used consists in preparing a suspension of the dried diluted substrate in 5 times its volume of water (1: 5), leaving it to stir for 5 minutes, and then resting it for at least two hours. The $\mathrm{pH}$ is read by a $\mathrm{pH}$ meter.

\subsubsection{Dry Matter (DM), Mineral Matter (MM) and Organic Matter (OM)}

The determination of dry matter content (DM) is carried out by drying in an oven. Poultry biomass samples, placed in porcelain crucibles, are dried at $105{ }^{\circ} \mathrm{C}$ for $24 \mathrm{~h}$. The empty crucible identified by a number is weighed, either $\mathrm{W}_{0}$. Then, the sample is placed in the crucible and weighed either $W_{1}$. Then, the crucible is placed in the oven and weighed after drying, either $\mathrm{W}_{2}$.

DM $(\%)=\left(\mathbf{W}_{2}-\mathbf{W}_{0}\right) /\left(\mathbf{W}_{1}-\mathbf{W}_{0}\right)$

To determine the mineral content (MM), we weigh the empty crucible identified by a number, either Wc. Next, 3 $\mathrm{g}$ of the sample are placed in a crucible and the full crucible is weighed, either $\mathrm{W}_{1} *$. After placing the crucible in the oven, it is weighed after drying, either $\mathrm{W}_{2} *$. Next, the crucible is placed in the furnace and weighed after incineration, either $\mathrm{W}_{3} *$.
The weight remaining after incineration corresponds to the MM.

MM $(\% \mathbf{D M})=(\mathbf{P 3} * \mathbf{P c}) /(\mathbf{P} 2 *-\mathbf{P c})$

The $\mathrm{OM}$ is determined by the following expression:

OM $(\%$ DM $)=100$ - MM (\% DM)

The determination of Total Organic Carbon (TOC) is obtained by deduction.

\% $\mathrm{TOC}=\% \mathrm{OM} / \mathbf{1 . 8}$

Note that the relationship between DM, MM and OM is expressed by the following formula:

$\mathbf{D M}=\mathbf{M M}+\mathbf{O M}$

\subsubsection{Determination of total nitrogen}

Nitrogen is measured by the Kjeldhal method [5], whose is based on the attack of the extract by concentrated sulfuric acid $\left(\mathrm{H}_{2} \mathrm{SO}_{4}\right)$. The organic nitrogen is transformed into ammoniacal nitrogen.

The nitrogen assay is based on the principle described in the following. In each digesting matras, $200 \mathrm{mg}$ of the substrate is introduced while avoiding placing on the neck of the matra, $5 \mathrm{ml}$ of concentrated sulfuric acid; this is the mineralization phase. After standing for 30 minutes, 200 mg of selenium catalyst are added and the matras are passed through the digester to heat for 1 hour until a yellow color is obtained; this is the digestion phase. After cooling, $30 \mathrm{ml}$ of distilled water is added to the flask and attached to the steam-driven apparatus and $30 \mathrm{ml}$ of sodium hydroxide solution are added to alkalize the medium; this is the distillation phase. The assay is carried out in an automated manner. The nitrogen contents relative to each substrate are displayed directly in a computer measurement plug connected to the distiller.

2.1.2.4. Determination of total volatile fatty acids by acid-base determination

The VFA concentration was evaluated by using the following assay method:

After the centrifugation of $10 \mathrm{ml}$ of the sample at 3000 rpm for 10 minutes, the sample is then diluted to a volume of $50 \mathrm{ml}$. Then, the sample is dosed with sulfuric acid $\left(\mathrm{H}_{2} \mathrm{SO}_{4}\right)$ to a $\mathrm{pH}$ of 3 , which then corresponds to the sum of the strong acids, in a partial neutralization of the weak acids and to a certain hydrolysis of present salts. The volume of acid added is denoted VA. Then, the sample is placed in a boil for 3 minutes on a hot plate. After cooling, the sample is dosed with $\mathrm{NaOH}$ until it reaches a $\mathrm{pH}$ of 6.5 . At this level, the added base volume is denoted VB. The concentration of the total VFA contained in the sample is calculated by using the following formula:

Total VFA $\left(\right.$ meq. $\left.\mathrm{L}^{-1}\right)=[(\mathrm{VB} \times \mathbf{1 0 0})-(\mathrm{VA}+100)] /$ $\mathbf{9 9 . 6 7} \times$ dilution factor

To obtain the concentration of total VFA in mg per liter, it is sufficient to multiply the value found by the molar mass of acetic acid which is equal to $60 \mathrm{~g} / \mathrm{mol}^{-1}$.

\subsection{Energy recovery of poultry droppings}




\subsubsection{Experimental Context}

Before installing the experimental biomethanation devices, it is first necessary to compare and select the process best suited to the study envisaged. In this regard, the physical nature of the biomethanizable substrate (wet or dry) and, on the other hand, the anaerobic digestion mode (batchwise or continuous) can be based. The batch wet process was used for the experimental biomethanation tests. In fact, the wet process (\% DM <15\%) is mainly developed to treat socalled liquid effluents (sludge, slurry, etc.). They can be used for solid waste, which then requires dilution. This process ensures good homogenization of the substrate and helps to optimize the transfer of material and heat and also to improve the production of the biogas.
In our study, $\mathrm{AD}$ was used in batch mode; the digesters were filled and after the end of the digestion, drained. At the end of the digestion, when the release of the biogas drops or becomes zero, the reactor is emptied and a new batch is introduced $[6,7]$. It is wet $8 \%$ DM. In the case of solid residues, their dilution must be done in order to obtain a concentration of 10 to $15 \%$ solids [8].

\subsubsection{Substrates used}

Several tests have been carried out to identify the effect of the nature of poultry substrate and the recovery medium and the effect of addition of inoculum on the quantity and quality of the biogas produced.

Table 1 summarizes the nature of the substrate and inoculum used for each test.

Table.1: Inputs used for each test

\begin{tabular}{lll}
\hline Test 1 & \multicolumn{1}{c}{ Biomass } & Inoculum \\
Test 2 & PD from a recovery pit & \multicolumn{1}{c}{-} \\
Test 3 & PD from a recovery pit & Fresh Cow Dung (FCD) \\
& PD from a recovery pit & $\begin{array}{l}\text { Fermentation Medium recovered from a rural digester } \\
\text { powered by on bovine manure (FM) }\end{array}$ \\
Test $\mathbf{4}$ & PD from a recovery pit & $\begin{array}{l}\text { Digestate Liquid comes from an AD of poultry } \\
\text { manure (DL) }\end{array}$ \\
Test 5 & PD from a recovery mat & - \\
Test 6 & PD from a recovery mat & FCD \\
Test 7 & PD from a recovery mat & FM \\
Test 8 & PD from a recovery mat & DL \\
\hline
\end{tabular}

\subsubsection{Introduced quantities}

In order to determine the quantity to be introduced, it is necessary to know the percentage of the DM of the dropping and of the inoculum to be used.
The volumes introduced for each test are given in the table below. The formula used for filling the digesters is as follows:

$$
\begin{gathered}
V_{\text {substrat }} \times \% D_{\text {substrat }}=V_{\text {digester }} \times \% \text { DM digester } \\
V_{w}(\text { volume of added water })=V_{\text {digester }}-V_{\text {substrat }}
\end{gathered}
$$

Table 2: Quantities introduced for each test

\begin{tabular}{lccccc}
\hline & PD $(\mathbf{m l})$ & Inoculum $(\mathbf{m l})$ & Water $(\mathbf{m l})$ & Digester $(\mathbf{m l})$ & Inoculum/Digester $(\%)$ \\
\hline Test 1 & 140,0 & 0,0 & 210,0 & 350,0 & - \\
Test 2 & 120,0 & 60,0 & 170,0 & 350,0 & $17 \%$ \\
Test 3 & 110,0 & 60,0 & 180,0 & 350,0 & $17 \%$ \\
Test 4 & 113,0 & 60,0 & 177,0 & 350,0 & $17 \%$ \\
Test 5 & 108,0 & 0,0 & 242,0 & 350,0 & - \\
Test 6 & 76,5 & 60,0 & 213,5 & 350,0 & $17 \%$ \\
Test 7 & 90,0 & 60,0 & 200,0 & 350,0 & $17 \%$ \\
Test 8 & 87,0 & 60,0 & 203,0 & 350,0 & $17 \%$ \\
\hline
\end{tabular}




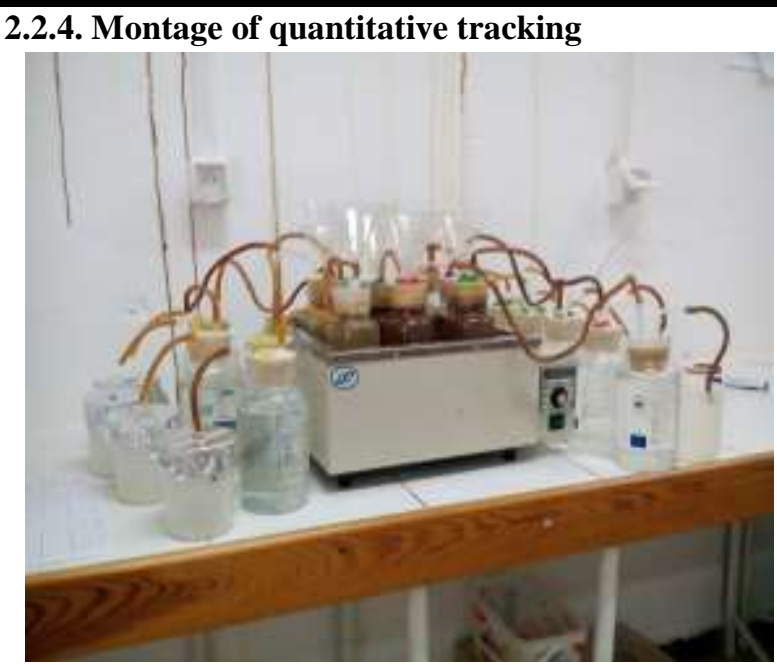

Fig.1: Experimental protocol for quantitative tracking of biogas produced

The core of the biomethanation device is the digester. A tank constituting the reactor into which the material to be treated is introduced is either continuous or discontinuous. The bioreactor is a closed and sealed system in which bacterial biomass carries out several biological reactions by consuming the organic matter present in droppings of laying hens in liquid medium to produce biogas. Sealing is essential to the success of the construction of a bioreactor because it allows remaining in the anaerobiosis (to prevent the entry of oxygen) and to prevent the escape of the biogas.

The quantitative tracking system consists of linking the experimental digester through the gas channel of the digester from a pipe while being careful not to leak. The flow rate of the biogas during the methane fermentation is followed by displacement of the water in a gasometer. The gas that will be produced from the bacteria will exert pressure on the water where the latter will be evacuated from the water pipe to be recovered in a graduated beaker. So the volume of water that will be released into the beaker is the volume equivalent of biogas produced.
For each test studied, two batches were performed in order to have an average of methanogenic potential. Fermentation until depletion of biodegradable organic matter allowed us to determine the yield of biogas. To evaluate the effect of temperature on the daily quantity of the biogas, experiments were carried out for two temperatures: $35^{\circ} \mathrm{C}$. and $55^{\circ} \mathrm{C}$.

\subsubsection{Qualitative monitoring of product biogas}

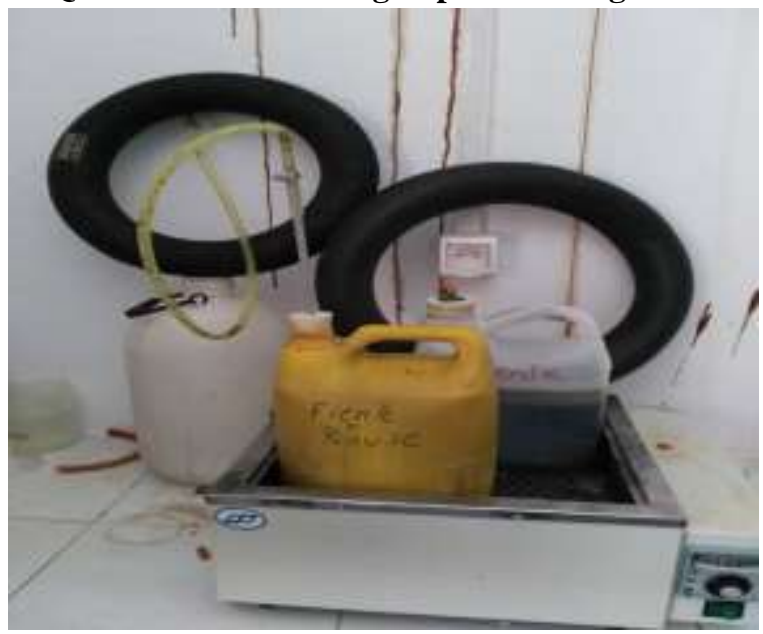

Fig2: Experimental protocol for qualitative tracking of biogas produced

For qualitative monitoring (Composition of the Biogas), five liter cans were fed with the same components of the $500 \mathrm{ml}$ digesters. The bioreactor is closed with a stopper connected to a flexible tube and completely empty thanks to a silicone pipe.

To assess the effect of substrate nature, recovery medium, inoculum change and temperature change on biogas quality, the same experiments performed for quantitative monitoring were repeated.

\section{RESULTS AND DISCUSSION}

3.1. Qualitative assessment of poultry biomass 3.1.1. Physicochemical evaluation of PD tested Table 3 illustrates the physicochemical parameters observed for each substrate studied.

Table 3: Physicochemical characterization of PD

\begin{tabular}{|c|c|c|c|c|}
\hline Parameter & $\begin{array}{l}\text { PD } \\
\text { Pit }\end{array}$ & $\begin{array}{c}\text { PD } \\
\text { Mat }\end{array}$ & $\begin{array}{c}\text { Result expressed in } \\
\text { bibliography }\end{array}$ & References \\
\hline pH & 8,8 & 7,3 & 6,5 to 8,8 and 8 to 9 & [9], [10] \\
\hline$\% \mathrm{DM}$ & 20,0 & 26,0 & 25 and $14<\% \mathrm{DM}<35$ & {$[10]$} \\
\hline$\% \mathrm{MM}$ & 50,0 & 32,0 & - & - \\
\hline$\% \mathrm{OM}$ & 50,0 & 68,0 & 58,0 & [11] \\
\hline$\%$ TOC & 27,7 & 37,7 & - & - \\
\hline $\mathbf{N t}$ & 11,0 & 16,0 & 15,0 & {$[10]$} \\
\hline $\mathrm{C} / \mathrm{N}$ & 2,5 & 2,3 & 3 to 8 and 4 to 8 & [9], [11] \\
\hline
\end{tabular}


Table 2 shows that the $\mathrm{pH}$ of different samples of droppings analyzed is in the range [7-9]. It is close

to that recommended by [9] and [10]. It is therefore favorable to the microbiological activity responsible for the degradation of OM. According to [9] organic matter was classified into three categories according to their consistency:

- Liquid (content <14\% DM), such as slurry, sewage sludge and vinasse;

_ Pasty fluid paste plastic $(14 \% \leq$ content $<35 \%)$, such as some manure, composts and sewage sludge;

- Solid (grade $\geq 35 \%$ ), such as certain composts and manures, solid and solid dry sewage sludge.
In our study, PD are of a pasty consistency and their DM levels are within the range recommended above by [9] and also by [10] who indicated that the DM content should be greater than $20 \%$ ( Below this threshold, the material is considered as a slurry).

The dropping recovered from the carpet is richer in OM than pit droppings, with $68 \%$ and $50 \%$, respectively, which is close to the guidelines mentioned in [11].

3.1.2. Physico-chemical characterization of each Inoculum used in the various tests

Table 3 presents the qualitative characterization of each inoculum used in the various assays.

Table.3: Qualitative characterization of the inoculum used in the various tests

\begin{tabular}{cccc}
\hline Parameter & FCD & FM & DL \\
\hline pH & 7,10 & 7,20 & 7,00 \\
\% DM & 13,40 & 4,00 & 6,00 \\
\% MM & 10,00 & 16,40 & 5,50 \\
\% OM & 90,00 & 83,60 & 94,50 \\
\% TOC & 50,00 & 46,40 & 52,50 \\
\hline
\end{tabular}

Table 3 shows that all the added leavens have a $\mathrm{pH}$ close to neutrality and are all rich in OM, especially the liquid manure digestate of poultry, this richness can favor the bacterial development and subsequently the production of Biogas

\subsection{Results of daily quantitative monitoring of the biogas produced for each test}

This part aims to describe the daily quantitative monitoring of biogas produced. The implementation of an operational monitoring of an experimental biomethanation protocol can fulfill several objectives and/or obligations, among others, control of the functioning of the digester and optimization of energy production. The monitoring of an experimental installation is essential for its proper functioning. Usually, it is necessary to ensure a minimum of monitoring of certain parameters, including control of equipment, monitoring of $\mathrm{pH}$ value,...

Currently, the anaerobic biodegradability of a waste is evaluated by measuring its methane potential. The most common test to measure the methane potential of a waste is the Biochemical Methane Potential test. It is more commonly called "BMP test" [12, 13]. This fermentation test involves placing a known quantity of waste in the presence of an adequate microbial inoculum under anaerobic conditions. At frequent intervals, the composition and quantity of biogas produced are measured in order to obtain the methane production as a function of time.

Several tests were carried out to evaluate the amount of biogas produced; each test involved a different parameter: nature of droppings (depending on the recovery medium), change in inoculum and also change in temperature. The curves represent the biogas produced for each test (cumulated over the fermentation time). The height of the tray corresponds to the value of the Biogas. The more biodegradable the input, the greater its methane potential.

3.1.3.1. Effect of change of recovery medium of poultry dropping on the daily amount of Biogas 


\section{Effect of change of recovery medium of poultry dropping on the daily amount of Biogas}

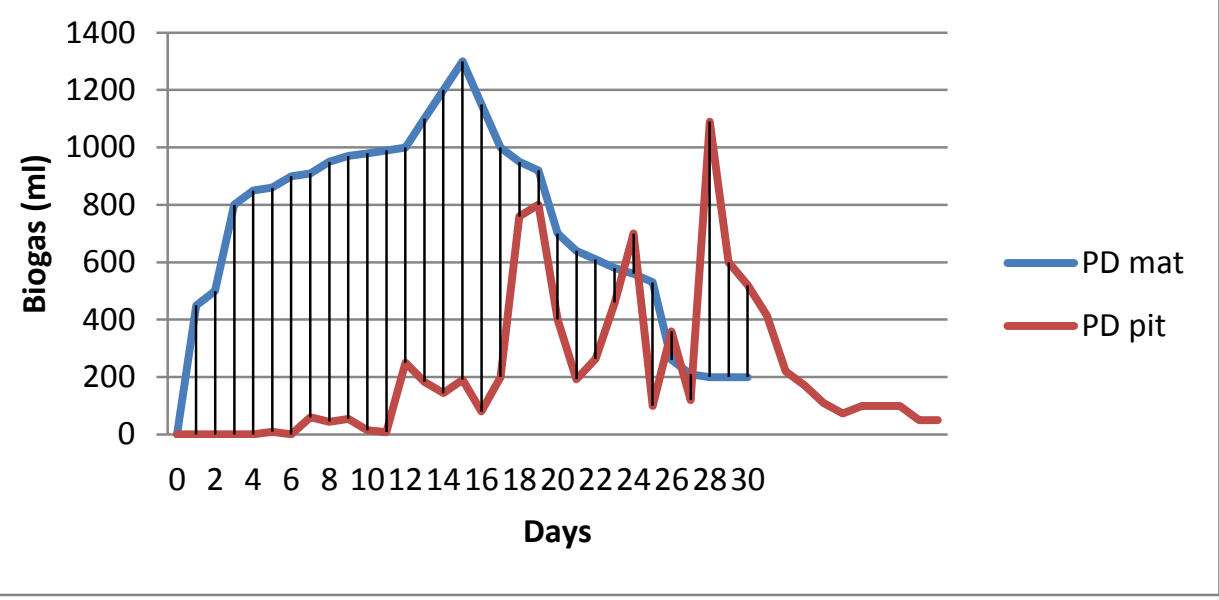

Fig.3: Effect of change of recovery medium of poultry dropping on the daily amount of Biogas

During methanation, groups of specific microorganisms will degrade OM. Thus, the production of methane will be dependent on the quantity of OM contained in this waste which is not the only parameter influencing the quantity of methane expected. Indeed, the quality of OM will also have a significant effect on the course of degradation reactions [14]. The quality and quantity of biodegradable OM contained in the waste plays a predominant role in optimizing the production of biogas. Indeed, the optimization of production is also carried out upstream of the digester, by the choice of waste to be methanized. The use of highly biodegradable waste increases the production of methane. Conversely, the degradation of low-biodegradable waste necessarily leads to a reduction in yield. It can thus lead to a loss of the microbial biomass due to the lack of metabolizable substrates. Thus, in AD, the quality of a waste corresponds to its capacity to be biodegradable.

Fig 3 illustrates the quantities of biogas produced per day with the change in the recovery medium of the droppings. The figure above allows us to conclude that the productivity of biogas depends on the type of methane organic material. It is higher in the case of picking biomass recovered from a recovery mat. The daily production is not constant for the two curves and it only started from the 7 th day for the digesters fed from the recovered pits from the recovery pit. While for digesters filled with dropping collected from a carpet, biogas production begins on the second day of the experiment while recording larger quantities. This is confirmed by the bibliography which shows that the higher the organic matter content of the substrate $(68 \%$ for carpet dung and $50 \%$ for pit ditch), the more matter to digest by the methanizing bacteria, Will have more biogas produced. These results agree with the theory of [15] which shows that the incoming organic charge is an important parameter and the residence time is inversely proportional to the charge: the less the substrate remains in the digester, the stronger the load. These parameters will weigh heavily on the amount of biogas produced. This explains the reduced residence time for the case of carpet dung.

3.1.3.2. Effect of change of inoculum added to poultry droppings on the daily production of Biogas in $\mathrm{ml}$ of displaced water

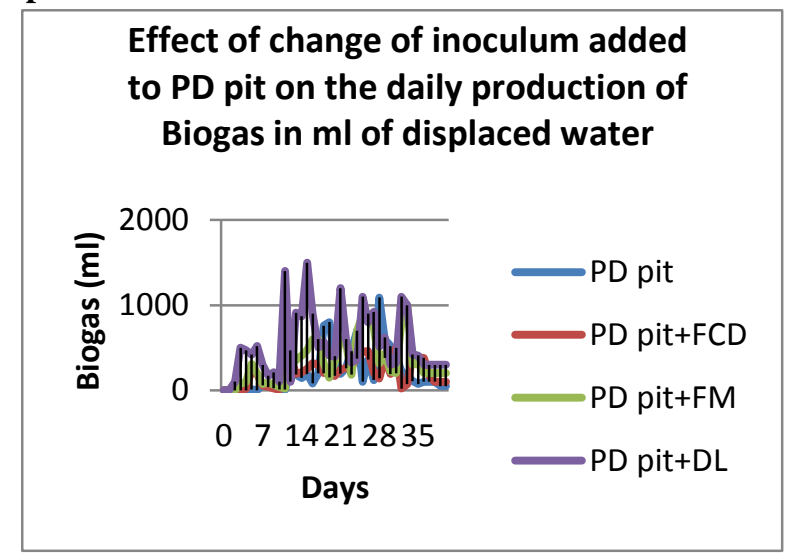

Fig.4: Effect of change of inoculum added to PD pit on the daily production of Biogas in $\mathrm{ml}$ of displaced water 
Effect of change of inoculum added to

PD mat on the daily production of

Biogas in $\mathrm{ml}$ of displaced water

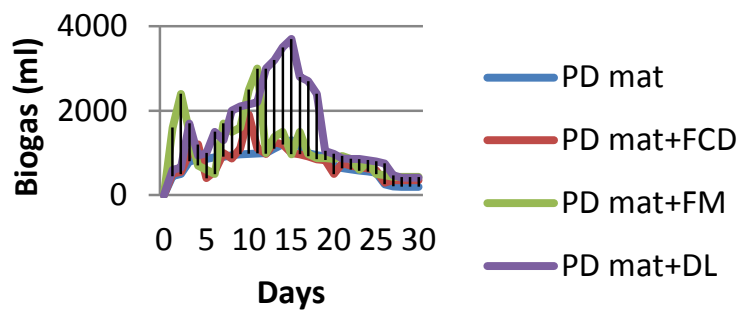

Fig.5: Effect of change of inoculum added to PD mat on the daily production of Biogas in ml of displaced water

This part is interested in evaluating the effect of change of inoculum on the daily amount of Biogas. The microbial inoculum or leaven comprises all types of microorganisms from different phases of Biomethanisation, such as fresh dung from the cow, recovered from an old digester or a laboratory-based consortium (mixture of substrates) [16, 17]. The daily quantitative monitoring without and with inoculum shows that for all the tests carried out, the addition of inoculum has improved the production of the Biogas, which in parallel has reduced the retention time. The use of digestate liquid from an old digester has greatly improved the amount of biogas produced especially mixed with the carpet or mat droppings with a peak that exceeds $3500 \mathrm{ml}$ on the 16th day of AD. The result obtained is in agreement with the result found by [18], which proved that biomethanization is very well adapted to the valorization of mixtures of waste, a true symbiosis is established and the yields obtained exceed the sum of the yields calculated for each substrate.

The presence of various peaks could be explained by the existence of fresh matter, which does not regularly arrive at the level of the bacteria and their evacuation which takes place before their complete decomposition.

3.1.3.3. Effect of change of temperature on the daily production of Biogas in $\mathrm{ml}$ of displaced wate

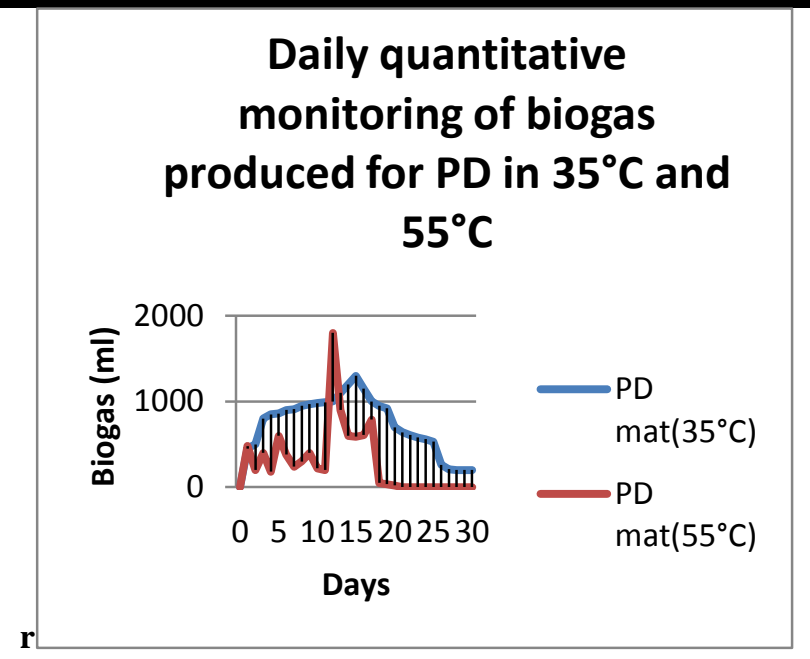

Fig.6: Daily quantitative monitoring of biogas produced for $P D$ in $35^{\circ} \mathrm{C}$ and $55^{\circ} \mathrm{C}$

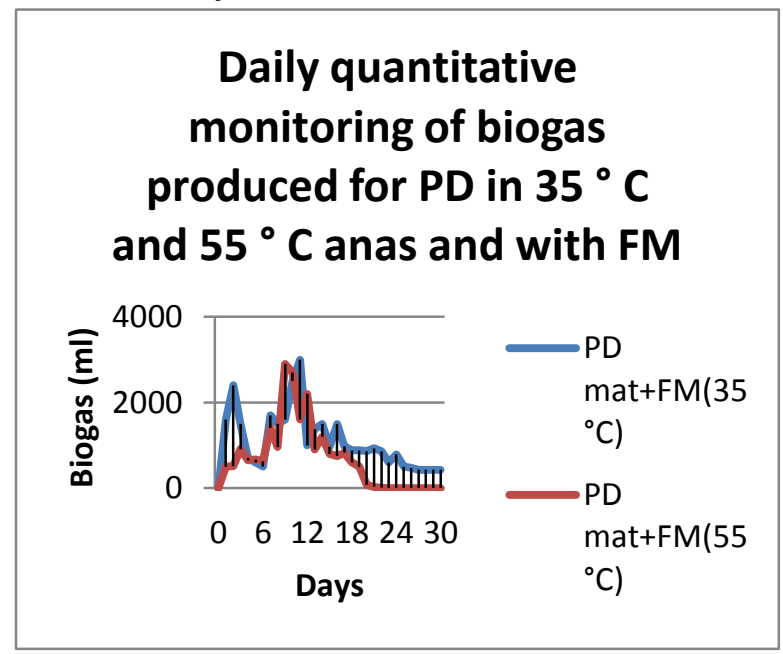

Fig.7: Daily quantitative monitoring of biogas produced for $P D$ in $35^{\circ} \mathrm{C}$ and $55^{\circ} \mathrm{C}$ anas and with $F M$

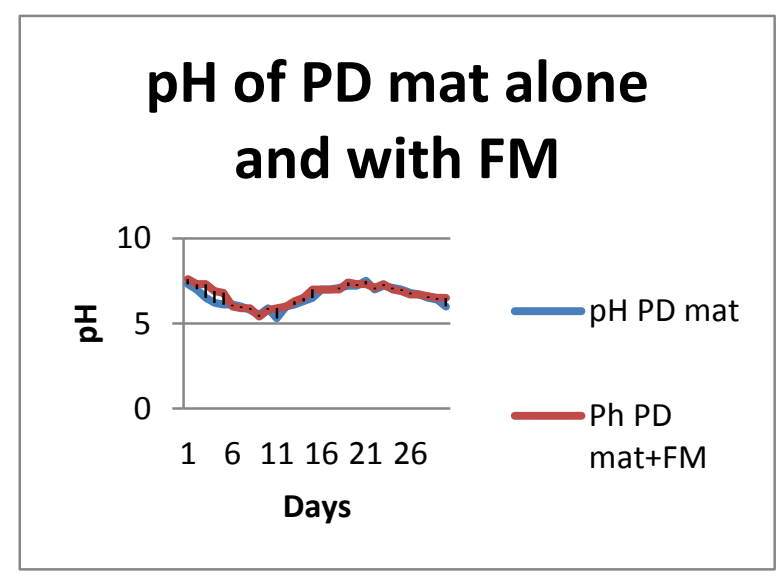

Fig.8: $p H$ of PD mat alone and with FM 


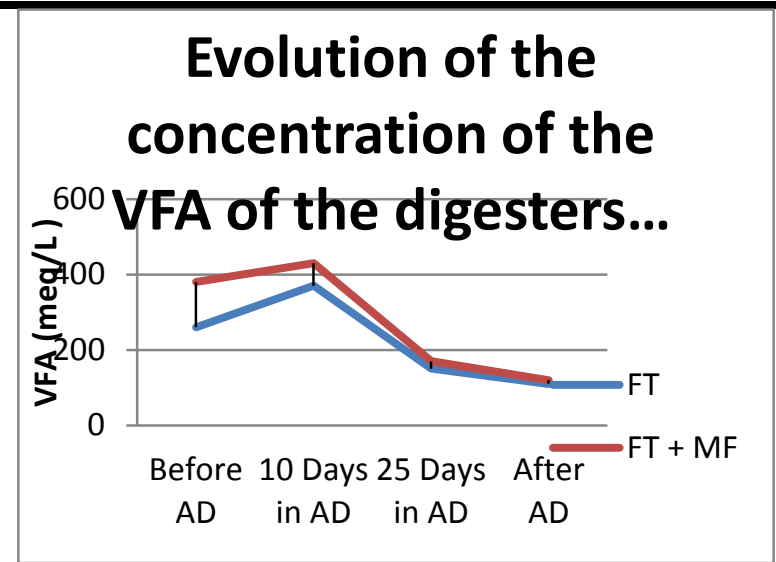

Fig.9: Evolution of the concentration of the VFA of the digesters fed by PD mat alone and with a FM

Digesters can be operated under mesophilic $\left(30-40^{\circ} \mathrm{C}\right)$, thermophilic $\left(50-60^{\circ} \mathrm{C}\right)$, or psychrophilic $\left(5-25^{\circ} \mathrm{C}\right)$ temperatures and with varying retention times; each with their own advantages and disadvantages. Typically thermophilic and mesophilic temperatures are preferred because they allow for higher amounts of organic loading, increased digester capacity, and shorter retention times [19]. The operational temperature inside the digester is one of the major parameters of the biogas production process. It has an effect on the level of biomethanogenic activity, the duration of the fermentation and its stability. Desai (1988) [20], reported by [17], noted that when the temperature of the digester was maintained at $40^{\circ} \mathrm{C}$ it was possible to reduce the retention time by more than $40 \%$.

According to [8], the mesophilic mode between 30 and $40^{\circ} \mathrm{C}$, with an optimal operating temperature of $35^{\circ} \mathrm{C}$, is the most used mode, due to its stability and good production of biogas. Moreover, mesophilic microorganisms are more robust and more tolerant to temperature variations, and are therefore more suitable for digesters with less controlled characteristics and localized in colder climates [7]. The average residence time is 3 weeks [6]. The results obtained (see figures) confirm those recommended in the bibliography and show that with the mesophilic mode the quantity of Biogas is greater in the case of the use of carpet droppings or with the addition of fermentation medium as inoculum.

3.1.3.4. Evolution of the amount of VFA in digesters during the trial period

The volatile fatty acids make it possible to check the progress of the anaerobic digestion process. A high level of VFA always goes hand in hand with a low pH. Fatty acids are produced during the first phase of digestion. The presence of too many fatty acids indicates that the second phase of digestion which cuts fatty acids, cannot keep pace with the production of acids. The reason may be a too short residence time or a too high polluting load for the treatment system [21].

If there is an imbalance in the system, usually it will lead to a buildup of VFAs, which will result in a decrease in $\mathrm{pH}$. This organic acid accumulation will not always result in an immediate drop in $\mathrm{pH}$ if the buffering capacity of the material is high, which is often the case with animal manures, so it is not usually the best indicator, but it is relatively easy to measure. The optimum $\mathrm{pH}$ for biogas production is between 6.7 and 7.4 , with digester performance decreasing when the $\mathrm{pH}$ is lower than 6 or higher than 8 [22].

The variation in $\mathrm{pH}$ as shown in fig. 11 leads us to say that there are two phases, the first phase representing the first 10 days of digestion during which there is a drop in $\mathrm{pH}$ to values close to 5.3 for both digesters. This decrease was accompanied by an increase in VFA of $260 \mathrm{meq} / \mathrm{L}$ to $370 \mathrm{meq} / \mathrm{L}$ and $380 \mathrm{meq} / \mathrm{L}$ up to $430 \mathrm{meq} / \mathrm{L}$ for PD digesters with fermentation medium and $\mathrm{PD}$ alone respectively. Figure 9 shows that the evolution of VFA concentrations is characterized by a common general pattern for both curves. The first phase corresponds to a stage where the acidogenesis phase prevails over the other phases of the fermentation. Indeed, the accumulation of VFAs in the bioreacter leads to a reduction in $\mathrm{pH}$ which may inhibit the fermentation process [23]. The second phase begins on the 11th day of the test, an increase and then a stability of the $\mathrm{pH}$ is observed, this being due to the adjustment of the $\mathrm{pH}$ by a basic solution $(\mathrm{NaOH})$ to maintain the $\mathrm{pH}$ at values between 6 and 7.5. This neutrality of the medium by addition of soda is necessary to promote the growth of methanogenic bacteria and also to limit the production and accumulation of VFA.

\subsection{Qualitative assessment of biogas produced}

The results of the analyzes relating to the composition in major elements of the biogas produced by the digesters tested are given in Table 4 . Table 4 summarizes the amounts of $\mathrm{CH}_{4}, \mathrm{CO}_{2}$ and $\mathrm{H}_{2} \mathrm{~S}$ found for each substrate under consideration. 
Table.4: Amounts of $\mathrm{CH}_{4}, \mathrm{CO}_{2}$ and $\mathrm{H}_{2} \mathrm{~S}$ found for each substrate under consideration

\begin{tabular}{lccc}
\hline & $\mathbf{C H}_{\mathbf{4}}(\boldsymbol{\%})$ & $\mathbf{C O}_{\mathbf{2}}(\boldsymbol{\%})$ & $\mathbf{H}_{\mathbf{2}} \mathbf{S}(\mathbf{p p m})$ \\
\hline Test 1 & 16 & 68 & 0,53 \\
Test 2 & 43 & 50 & 1,70 \\
Test 3 & 54 & 35 & 0,32 \\
Test 4 & $\mathbf{6 3}$ & $\mathbf{3 0}$ & 1,00 \\
Test 5 & 23 & 63 & 0,32 \\
Test 6 & 45 & 33 & 0,50 \\
Test 7 & 60 & 28 & 1,00 \\
Test 8 & $\mathbf{7 0}$ & $\mathbf{2 0}$ & 1,20 \\
\hline
\end{tabular}

Some of the indicators of system imbalance include changes in: biogas production, biogas composition $\left(\mathrm{CH}_{4}\right.$, $\left.\mathrm{CO}_{2}, \mathrm{H}_{2}\right), \mathrm{pH}$, alkalinity, volatile fatty acids, volatile solids reduction, chemical oxygen demand (COD) reduction, and the carbon to nitrogen $(\mathrm{C} / \mathrm{N})$ ratio. The biogas production and composition is closely tied to the level of organic loading. Oftentimes when the digester is overloaded, it will respond with an immediate increase in biogas production, but then a sudden decrease when levels of inhibiting products (acids) are too high and $\mathrm{pH}$ drops. Strong imbalances like this can also cause variations in the biogas composition, such as a shift to higher levels of $\mathrm{CO}_{2}$ and $\mathrm{H} 2$, because they are not consumed fast enough by the $\mathrm{H} 2$ utilizing methanogens [22].

The quality of the biogas is evaluated essentially by the percentage of methane $\left(\mathrm{CH}_{4}\right)$ it contains. A biogas is all the better as its percentage of methane is high [24]. In the case of experimental digesters, the percentage of $\mathrm{CH}_{4}$ produced generally increased with increasing incoming of $\mathrm{OM}$ concentration in the digester. It should be noted that the methane content is important after the addition of a liquid digestate as an inoculum. Similarly, the percentage of $\mathrm{CO}_{2}$ also decreased with the percentage increase in methane.

\section{CONCLUSION}

In the light of the results obtained, during the various tests carried out, we obtained some interesting information about the effect of OM concentration, inoculum change and temperature both on quantitative gas productivity and on the composition of the Biogas.

It was found that the higher the OM concentration of the substrate, the better the digester performance.

It appears that poultry droppings require seeding of methanogenic bacteria to improve the quantity and quality of the biogas produced, in our case several types of inoculum have been inoculated: cow dung, bovine fermentation medium of a digester and a liquid digestate from an old digester supplied by poultry manure. The most stable and continuous maximum production is obtained with the mixing of poultry droppings with the liquid poultry digestate with a mesophilic fermentation $\left(35^{\circ} \mathrm{C}\right)$ characterized by agitation twice a day and a dry matter concentration equal to $8 \%$ (Wet). The use of liquid digestate as an inoculum for Biomethanisation applied to poultry biomass may both, improve the quantity and quality of the biogas produced and also reduce the amount of water used for the dilution of effluents, just add the liquid digestate recovered from previous $\mathrm{AD}$ test and so on.

\section{REFERENCES}

[1] Groupement Interprofessionnel des Produits Avicole et Cunicoles ; GIPAC., 2015.

[2] I. A. Znaïdi., Etude et évaluation du compostage de différents types de matières organiques et des effets des jus de composts biologiques sur les maladies des plantes. Mémoire de Mastère Institution Agronomique Méditerranéenne de Bari, 104 p., 2002.

[3] B. Pierre, C. Matthieu, 1. Olivier and V. Javier. Guide méthodologique pour l'exploitation d'unités de méthanisation de déchets solides, Juillet 2007.

[4] Les Déjections avicoles, Sciences et Technologie Avicoles; hors série, Septembre 2001.

[5] S. Goyal, S.K. Dhull and K.K. Kapoor, Chemical and Biological Changes During Composting of Different Organic Wastes and Assessment of Compost Maturity, Bioresource Technology, Vol. 96, pp. 1584-1591, 2005.

[6] Agence de l'Environnement et de la Maîtrise de l'Energie (ADEME) (s.d.). Méthanisation. In Site de l'ADEME, Déchets, Traitements biologiques. http://www2.ademe.fr/servlet/KBaseShow?sort=$1 \&$ cid=96\&m=3\&catid=15556 (Page consultée le 28 janvier 2010).

[7] K. Ostrem. Greening Waste: Anaerobic digestion for treating the organic fraction of municipal solid 
wastes. Mémoire de maîtrise, Columbia University, New York, 2004.

[8] N. Bernetet et P. Buffière, Caractérisation de la mise en œuvre de la méthanisation. In Moletta, R., La méthanisation (chap. 4, p. 87-113). Paris, Éditions Tec \& Doc, 2008.

[9] Rapport final de l'ESCo "Matières fertilisantes d'origine résiduaire"; Chapitre 2. Caractéristiques physico-chimiques et biologiques des Mafor, octobre 2014.

[10] Fiche matières organiques, Fiche de poule pondeuse, Février 2007.

[11]P. Levasseur et C. Aubert. Contexte, Atouts et Faiblesses des Effluents Porcins et Avicoles Destinés à Être Exportés, ESA d'Angers, Vol. 29, N², 9 p, 2006.

[12]I. Angelidaki and al Defining the biomethane potential (BMP) of solid organic wastes and energy crops: a proposed protocol for batch assays, Q IWA Publishing 2009 Water Science \& TechnologyWST $\mid 59.5$ | 2009.

[13][13] Hansen and al: Carbonaceous aerosols in the industrial era. Eos Trans. Amer. Geophys. Union, 85, no. 25, 241, 245, 2004.

[14]P. BUFFIERE, Guide méthodologique pour l'exploitation d'unités de méthanisation de déchets solides, Juillet 2007.

[15]E. ADLER. Le biométhane, une énergie naturelle renouvelable qui a fait ses preuves, Cabinet ACONSULT Centre d'Affaires des Monts d'Or, pp 16, 2009.

[16] OR. Kotsyurbenko, AN. Nozhevnikova, GA. Zavarzin. Methanogenic degradation of organic matter by anaerobic bacteria at low temperature. Chemosphere 27: 1745-1761, 1993.

[17] A. Yadvika, A.Santosh, T. R. Sreekrishan, S. Kohli, V. Rana. Enhancement of Biogas Production from Solid Substrates Using Different Techniques, 2004. Bioresource Technology, 95. Energy Information Administration. http://www.eia.doe.gov/emeu/cabs/usa.html. November 27, 2005.

[18] M. Wauthelet. Rapports d'expertise sur le projet pilote à Dayet Ifrah - Missions de 1 à 4 (in French) Expert reports about the pilot project Dayet Ifrah Missions 1 to 4. GIZ, Programme AGIRE, Rabat, Morocco, (2009).

[19] O. Wohlgemut, Co-Digestion of Hog Manure with Glycerol to Boost Biogas and Methane Production, A Thesis submitted to the Faculty of Graduate Studies The University of Manitoba In partial fulfillment of the requirements for the degree of Master of Science, 2011.

[20] C. K. Desai. Use of solar pond for thermal control of biogas plant. In: Proceedings of the National Seminar on Solar Energy and Rural Development, Kolhapur, May 29-31, 1987. Shivaji University, pp. 83-88, 1988.

[21] S. Ludwing. DEWATS. Systemes Décentralisés de traitement des eaux usées dans les pays en voie de développement, 1998.

[22] Poulsen, Tjalfe G. Anaerobic digestion. In Solid Waste Management. Aalborg University, Denmark, 2003..

[23]P. DELFOSSE, Microbiologie de la Digestion Anaérobie, compte rendu de la présentation de philippe delfosse (centre de recherche public gabriel lippmann), Février 2010.

[24] Y. M'SADAK. et R. I. ZOGHLAMI. Caractérisations physico-chimique, environnementale et énergétique de la biométhanisation industrielle avicole en Tunisie semi-aride, Algerian journal of arid environment vol. 2, $\mathrm{n}^{\circ}$ 2, Décembre 2012. 